\title{
Андрій Баумейстер
}

\section{НА ШЛЯХУ ДО АВТЕНТИЧНОГО БУТТЯ: ФЕНОМЕНОЛОГІЧНА ДЕСТРУКЦІЯ АРИСТОТЕЛЯ У РАННЬОГО ГАЙДЕГЕРА}

Гайдегерове звернення до первинного досвіду християнського життя не мало на меті розробку нового варіанту теології або християнської філософії (попри згаданий вислів $з$ листа до Левіта). Гайдегерові йшлося про зовсім інше: у курсах 1920-1921 pp. здійснюються перші спроби розробити й випробувати методологію так званої феноменологічної герменевтики. Листи апостола Павла, Августин, середньовічна містика - все це обирається за парадигматичні приклади, покликані відкрити доступ до первинного досвіду життя у його визначальних рисах і конститутивних характеристиках. У зимовому семестрі 1921/1922 року таким парадигматичним прикладом постає філософія Аристотеля.

\section{1. Діалог з Аристотелем і метод феноменологічної (герменевтичної) деструкції}

Чим зумовлена така зміна перспективи? Чи достатньо пояснити Гайдегерів вибір лише випадковими зовнішніми обставинами (тим, що лише деякі студенти мали теологічну освіту і треба було запропонувати інші тексти для аналізу) [Артеменко, 2012: с. 14]? Навряд чи. Адже коли Гайдегер за три тижні (з кінця вересня до середини жовтня 1922 року) пише Паулю Наторпу манускрипт «Феноменологічна інтерпретація Аристотеля» (відомий також як Natorp-Bericht), він уже працює (з літа 1922 року) над книгою про Аристотеля і навіть заявляє про ії майбутню публікацію [Гадамер, 2007: с. 160]. Іншими словами, теза про випадковий вибір осені 1921 року передбачає, що Гайдегер цілком несподівано потрапляє у зовсім новий контекст мислення, відтак починає шлях до зовсім нового первинного досвіду. I цей новий контекст настільки його захоплює, що він береться за дослідження з Аристотеля і пов'язує своє можливе професорство у Марбурзі саме із завданням тлумачення Стагіритової філософії.

Тезу про несподіваний початок здається підтверджує і Гадамер. Він каже про «несподіваність» результатів Аристотелевої екзегези і для самого Гайдегера [Гадамер, 2007: с. 41]. Теодор Кісел висловлюється ще промовистіше: несподіване повернення до Аристотеля так глибоко позначилося на Гайдегеровому мисленні, що цей інтелектуальний вплив залишався визначальним протягом усього творчого шляху німецького філософа [Kisiel, 1993: p. 228]. Тут навіть важко говорити про інтерпретацію у строгому сенсі, бо, за Гадамером, Гайдегер був націлений на свій власний

(C) Баумейстер, 2013 
проект, протилежний до метафізики. Це раннє тлумачення Аристотеля відзначалося тим, що воно стерло відчужувальні схоластичні викривлення й стало ледь не взірцем герменевтичного «злиття горизонтів», завдяки якому Аристотель заговорив ніби як наш сучасник [див. Гадамер, 2007: с. 161].

Необхідно відзначити дві обставини, що дозволяють краще зрозуміти звернення до «нового початку». (1) У зимовому семестрі 1921/1922 років Гайдегер читає курс лекцій «Феноменологічна інтерпретація Аристотеля» і паралельно веде просемінар, де базовим текстом обирається другий том Гусерлевих «Логічних досліджень». Така паралель продовжиться і в літньому семестрі 1922 року. Цікаво, що у зимовому семестрі 1922/1923 років Гайдегер знову читає лекційний курс з Аристотеля (Нікомахова етика VI, De anima, Метафізика VII) і паралельно веде семінар 3 «Ідей чистої феноменології» («Ідеї» I). Для Гайдегера Аристотель постає як прото-феноменолог, як мислитель, що дозволяє більш радикально підійти до первинного досвіду феноменологічного убачання. (2) Філософія Аристотеля, особливо Стагіритове вчення про phronêsis відкриває для Гайдегера досвід життя, сумірний із досвідом, описаним у листах апостола Павла.

I в Natorp-Bericht, і в лекціях зимового семестру 1921/1922 років, поняття «тутбуття» і «фактичне життя» знову постають як синоніми. Іншими словами, терміни Dasein i Leben мають взаємно тлумачити один одного. Стагіритова філософія інтерпретується з певної «герменевтичної ситуації», що мусить бути ясно визначена. Минуле розкриває себе із завжди живого теперішнього [див. Хайдеггер, 2012: с. 46]. Іншими словами, розуміння минулого можливе тільки виходячи 3 конкретної ситуації «тепер», з ситуації конкретного перед-розуміння.

У лекціях ця ситуація описується детальніше: мається на увазі «дух часу», виражений у вимозі строго досліджувати факти (strenge Tatsachenforschung) [Heidegger, 1995: S. 1]. Нарешті предметом філософського дослідження оголошується людське буття (das menschliche Dasein) і фактичне здійснення глибинного руху фактичного життя [див. Хайдеггер, 2012: с. 49 і с. 55]. Цікаво, що визначення головного предмета філософського дослідження (людське буття) тут інше, ніж у «Бутті й часі», де «фундаментальним» і «головним» питанням філософії постає питання про буття, Seinsfrage. Також важливо відзначити, що вихідний пункт лекцій з Аристотеля має схожість із початком курсу з «Феноменології релігії»: Гайдегер відштовхується від досвіду філософування.

Але у зимовому курсі 1921/1922 року, одразу вказується, що філософування «осяжне тільки як екзистенція», «доступне у контексті чистого фактичного життя (zugänglich aus dem rein faktischen Leben), тобто в історії і через історію» [Heidegger, 1994: S. 1]. Так в одному реченні поєднуються: філософування, екзистенція, фактичне життя й історичність. Філософія власне і $є$ «історичним пізнанням фактичного життя» [Heidegger, 1994: S. 2]. Але саму філософію не можна «просто» схопити у дефініції. Йдеться не про те, аби спочатку дати визначення філософії, а потім братися за філософське пізнання життя.

Ідея визначення, логіка осягнення предмета, отримують свою силу і чинність із того способу, «у який предмет первинним чином стає доступним (wie der Gegenstand ursprünglich zugänglich wird)» [Heidegger, 1994: S. 20]. Важливо отримати доступ до «первинної ситуації очевидності» (ursprüngliche Evidenzsituation), в якій може відбутися принципове рішення філософувати (die Situation der Urentscheidung der Vollzüge des Philosophieren (Existenz) ) [Heidegger, 1994: S. 35]. Отже, йдеться про досвід, в якому 
предмет власне дає себе так, як він є. Ми завжди філософуємо з певної ситуації, але саму цю ситуацію ми залишаємо поза запитуванням. Саме філософське дослідження, за Гайдегером, становить певний модус «як» фактичного життя [див. Хайдеггер, 2012: c. 55]. Тобто філософія є одним із виявів способу перебування, вона не може бути притягнута ззовні або постфактум як певний засіб або «техне».

Що може допомогти прояснити й виявити особливість і конкретність ситуації філософування? Гайдегер дає досить несподівану відповідь, яку ми, радше, приписали би Вітгенштайну чи Остіну, ніж німецькому філософу 20 -х років. Він обирає за герменевтичний засіб мововжиток (Sprachgebrauch). «В орієнтації на ужиток мови проступає певна ситуація розуміння (mit der Vorgabe eines Sprachgebrauchs ist eine Verstehenssituation aktuiert)» [Heidegger, 1994: S. 42]. Якщо триматися мовно-ситуаційного орієнтира, то філософія сучасності постане у контексті опозиції «світоглядної» і «наукової» філософій. Для Платона ж філософія постає в іпостасі «як» само-поводження (ein Wie des Sichverhaltens) і ніколи як «техне» [Heidegger, 1994: S. 50]. У дослідженні контекстів Платонового ужитку слова «філософія» саме й виявляє себе вперше «виражальна тенденція мововжитку» (die Ausdruckstendenz des Sprachgebrauchs). Ця Платонова практика мово-вжитку дозволяє дистанціюватися від сучасного підходу до філософії - як до наукової дисципліни, як до засобу об’єктивації. Отже, філософія пов'язана 3 певним само-поводженням, $з$ поведінкою (Philosophieren ist ein Verhalten) [Heidegger, 1994: S. 53]. Поводження ж передбачає стосунок до чогось, сенс стосунку (Bezugssinn). Філософування, згідно з власним сенсом стосунку, $є$ пізнавальним стосунком (erkennendes Verhalten). Йдеться про такий стосунок, який не має особливої області дослідження, він націлений на щось принципове, первинне. Філософія - це пізнавальний стосунок до сущого і до принципу сущого - до буття (erkennendes Verhalten zu Seiendem als Sein) [Heidegger, 1994: S. 58]. Але таке визначення потребує прояснити спосіб стосунку до буття, Wie seines Vollzugs. Такий хід мислення приводить Гайдегера до твердження, важливого з методологічного погляду: філософія $\epsilon$ онтологією, а саме «радикальною, і у своїй радикальності феноменологічною (екзистенційною), тобто - онтологічною феноменологією» [Heidegger, 1994: S. 60]. Таке «визначення» знову ставить питання про ситуацію, в якій ми можемо отримати доступ до філософування.

Гайдегер повертається до поняття das faktische Leben, позаяк філософія є фундаментальним «як» самого життя (ein Grundwie des Lebens selbst). «Життя» постає тут як феноменологічна основна категорія і позначає «основний феномен». Проміжний результат коротко можна описати так: виходячи з досвіду філософування ми мусимо спочатку звернути увагу на те, як витлумачується така справа, як «філософія» (проблематизація поняття «дефініції» і «принципу»). Ми не можемо виходити 3 готового визначення філософії як з чогось зовнішнього. Філософія є історичним пізнанням фактичного життя і може стати зрозумілою тільки 3 фактичного життя. Обраний герменевтичний засіб (аналіз мовного вжитку) дозволяє виявити конкретну ситуацію розуміння, у рамках якої намагаються схопити щось таке, як «філософія». I якщо сучасний мовний контекст пропонує нам опозицію «світоглядної» і «наукової» філософій, то мовний узус Платона показує інший образ філософії - як певне поводження й прагнення осягнути не ту чи іншу предметну сферу, а буття сущого. Питання про досвід філософування перетлумачується тут як питання про властивий спосіб стосунку до буття сущого. Відтак феноменологія постає як онтологічна феноменологія. I при цьому досвід, стосунок, поводження завжди розуміються як способи здійснення фактичного життя. 
Очевидно, що тут виникає коло: щоб уможливити розуміння досвіду філософування ми маємо витлумачувати його як історичний досвід фактичного життя. Але, 3 іншого боку, ми маємо тоді розуміти саме фактичне життя, а це розуміння передбачає досвід філософування, що розгортається в історії. Ще коротше: автентичний досвід філософування відкривається (стає зрозумілим) тільки у фактичному житті. Але фактичне життя, у свою чергу, стає зрозумілим саме у досвіді філософування.

Досягнутий результат дозволяє з іншої перспективи підійти до аналізу фактичного життя, аби виявити, що саме розкривається у цьому «основному феномені» (was im Phänomen „Leben“ als solchem mit da ist, in ihm selbst sinnmäßig mitbegriffen wird) [Heidegger, 1994: S. 85]. Іншими словами дослідження змінює напрям руху, аби побачити, що показує фактичне життя у своєму «тут» $(d a)$. Перша «феноменологічна категорія» що позначає сенс різноманітних стосунків життя - це «світ». Життя саме по собі світо-спрямоване (weltbezogen). Ми бачимо, що Гайдегер ще користується терміном «категорія» як основним інтерпретативним засобом для опису фундаментальних характеристик фактичного життя в його стурбованості [Heidegger, 1994: S. 87]. Хоча він і зауважує, що йдеться про «нові» категорії. Такі категорії не щось винайдене; вони «у первинний спосіб перебувають у самому житті» ніби у власному життєвому середовищі (sie sind in ursprünglicher Weise im Leben selbst am Leben) [Heidegger, 1994: S. 88]. Фактичне життя перебуває у такий спосіб, що воно у дочасності свого буття стурбоване власним буттям [див. Хайдеггер, 2012: С. 49-50]. Фактичне буття завжди є своїм власним, воно не є буттям взагалі [див. Хайдеггер, 2012: с. 53]. Основний сенс рухливості фактичного життя - турбота. Світ присутній для фактичного життя у турботі (Sorgen) й артикулюється відповідно до можливих спрямованостей турботи: як довколишній світ, спів-світ і світ-самого-себе [див. Хайдеггер, 2012: С. 57-58]. Вчитуючись у ці стислі формули, ми вже можемо бачити перші підступи до майбутнього проекту «Буття й часу».

Варто відзначити, що в лекціях зимового семестру 1921/1922 років, попри їх назву («Феноменологічна інтерпретація Аристотеля») сам Аристотель майже не згадується (якщо не враховувати двох-трьох випадків). Так само і в першій частині Natorp-Bericht («Експозиція герменевтичної ситуації»), яку слід уважати коротким резюме згаданого лекційного курсу, ім'я Стагірита з'являється тільки наприкінці. Натомість можемо помітити інтенсивну роботу з концептуальною системою Аристотеля і намагання передати ії в нових термінах у зовсім іншому контексті. В Аристотеля Гайдегер знаходить важливу думку: у досвіді щоденного життя, у щоденній орієнтації на добре життя, виявляє себе особливе знання, що не може бути до кінця об'єктивованим. Таке знання, максимально наближене до життєвих першоджерел, Аристотель називає розсудливістю, phronêsis. Йдеться про розуміння, що виявляє себе у вчинках і рішеннях.

У «Нікомаховій етиці» phronêsis описується так: «А розсудливим здається той, хто здатний приймати вірні (kaloss) рішення у зв'язку із благом і користю для нього самого (peri ta aytô agatha kai sympheronta), однак не в частковостях..., але загалом: що корисне для доброго життя (pros to ey dzên holôs). Підтверджується це тим, що ми говоримо про розсудливих у якомусь відношенні, коли люди зуміли добре розрахувати, що треба для досягнення певної доброчесної мети (pros telos ti spoydaion), [для досягнення якої] не існує мистецтва (ôn mê esti technê). Отже, хто здатний приймати розумні рішення, той і розсудливий у загальному значенні слова» (EN VI, 1140 a26-30 - переклад Віктора Ставнюка). Далі Стагірит роз'яснює, що такі 
вірні (буквально «прекрасні») рішення не приймаються стосовно чогось необхідного, а тільки стосовно того, щзо може бути іншим. Ми пам'ятаємо, що необхідну предметність досліджують теоретичні науки (сфера діяльності noys i sophia), а те, що може бути іншим належить до сфери практики. Отже, йдеться про практичне знання. У практичному житті має місце ситуативна раціональність - розуміння, що походить 3 самої життєвої конкретики і належить до компетенції істот, що користуються логосом, мають власні изілі і на основі логосного існування керуються уявленнями про благо і зло.

Гайдегер перекладає phronêsis як «турботливий огляд» (fürsorgende Umsicht), «турботлива оглядовість» (fürsorgliches Sichumsehen). Phronêsis - це проясненняобходження (Umgangserhellung), спів-часове життю у його бутті [див. Хайдеггер, 2012: c. 130]. У турботливій оглядовості фактичне життя «обходиться» 3 речами світу. В такому обходженні світ постає назустріч [життю] в характері значимості (Bedeutsamkeit) [див. Хайдеггер, 2012: с. 59]. Турботливе обходження спроможне також ніби «перегородити» власне прагнення правити (Verrichtung) і встановлювати (Ausrichtung), і тоді воно перетворюється на «лише» видивляння (Hinsehen auf) [див. Хайдеггер, 2012: C. 59-60]. Вживаючи таку майже езотеричну мову, Гайдегер намагається показати (1) первинність практичного знання, а також (2) спосіб походження теоретичного знання (з його споглядально-об'єктивуючими настановами) від життєвих контекстів праксису. У теоретичній настанові фактичне життя створює для себе поле нових буттєвих можливостей, пов'язаних із відкриттям предметоутворювальних здатностей. Тоді світ, що постає назустріч, постає у вигляді предметів і речовинності речей. Але у тих або тих виявах турботливого обходження, «фактичне життя завжди рухається у витлумаченості» [див. Хайдеггер, 2012: с. 62]. Тобто, розуміння є життєвою динамікою, певним онтологічним модусом. У витлумаченості світу фактичне життя утримує саме себе у турботі. Так встановлюється певний сенс життєвого тут-буття (Lebensdasein) [див. Хайдеггер, 2012: с. 63].

У турботі для фактичного життя дається світ, що постає у характері значимості. Але цей стосунок до світу може мати тенденцію до відпадіння життя від самого себе (Abfallen von sich selbst), тенденцію до падіння у світ (Verfallen an die Welt), до розпаду життя (Zerfallen seiner selbst) [див. Хайдеггер, 2012: с. 65]. Така тенденція внутрішньо належить життю і не $\epsilon$ чимось «поганим» або «неприпустимим». Вона виражає прагнення життя полегшити свій буттєвий тягар, «освоїтись»у просторі анонімної зрозумілості, у заспокійливому осередку публічності. У своїй заспокійливості, тенденція до падіння все більше відчужує фактичне життя від нього самого [див. Хайдеггер, 2012: с. 69]. Схильність до падіння постає причиною того, що фактичне життя, яке є по-суті фактичним життям окремої людини, не проживається як таке [див. Хайдеггер, 2012: с. 70]. Тоді життя рухається в рамках певної посередності (Durchschnittlichkeit) турботи, у посередності відповідної публічності (das «Man»). Дехто, das «Man», фактично живе життям окремої людини, але в такому разі фактичне життя проживається «ніким» (Niemand), воно занурене у «невласну» (uneigentlich) традицію і звичку [див. Хайдеггер, 2012: с. 71]. Життя ніби втікає від самого себе (Weggehen des Lebens).

Найвиразніше цей глибинний рух втечі життя від самого себе виявляється у ставленні до смерті. Смерть $є$ для фактичного життя чимось таким, перед чим життя поставлене (bevor stehet). Знання про це перед-стояння смерті виявляється конститутивним для буттєвого характеру фактичності [див. Хайдеггер, 2012: с. 73]. Смерть $є$ 
таким феноменом, 3 якого належить експліцитно виводити часовість людського буття [див. Хайдеггер, 2012: с. 74]. Йдеться не про моральну, теологічну або метафізичну оцінку смерті. Йдеться радше про онтологічні структури, про фундаментальні модуси і конститутивні тенденції фактичного життя. Сам Гайдегер каже про конститутивні модуси «як» рухливості життя. Тенденція до падіння є тим обхідним шляхом (Umweg), що може відкрити доступ життю до власного буття. Саме тоді, коли життя протидіє своїй внутрішній тенденції до падіння, може бути схоплене властивим чином його власне буття. Таке буття, доступне саме собі у фактичному житті, Гайдегер пропонує позначити як екзистенщію [див. Хайдеггер, 2012: с. 77]. Екзистенція розкривається як можливість бути у власний спосіб, як онтологічна спроможність. Ї̈ можна «схопити», але можна й «випустити». У фактичності сконцентрована можлива радикальна проблематика буття певного життя [див. Хайдеггер, 2012: с. 81]

Стратегія Гайдегера полягає у тому, щоби філософію, попри ії «піднесеність», «привести до життя» [Figal, 1992: S. 63]. У «Бутті й часі» phronêsis буде перетлумачено в сенсі «буттєвої зрозумілості». «Гайдегер орієнтується на первинне знання про життя та життєвість і зводить розвинену форму теоретичної філософії до первинної форми філософії практичної» [Figal, 1992: S. 60]. Наскільки виправдане таке зведення «теорії» до практичної філософії? Якщо відповідати на це запитання з позиції «наміру автора» (в даному випадку - Аристотеля), то запропоноване Гайдегером тлумачення є невиправданим насильством над Аристотелевими текстами. Більш того, приклад Гайдегерової інтерпретації показує, як намір тлумачити Аристотеля поєднується із фактичним запереченням головних передумов Стагіритової думки. У самого Аристотеля безумовний онтологічний і епістемологічний примат має теоретичний ум (noys), що його намагається втілити людина у своєму етосі й полісі.

Ми тут маємо справу зі своєрідним «перевертанням цінностей». «Божественність» першої філософії (власне, певна ії над-людськість) відкидається на користь ії нібито фактично-людської природи. Все скидається на те, що така інтерпретація бере окремий аспект чи сюжет Аристотелевої концепції філософії, вириває його із властивого контексту, повністю змінює його сенс і включає цей сюжет у зовсім інший інтелектуальний контекст (не забуваймо, що Natorp-Bericht називають першим ескізом «Буття й часу»). Аристотель, згідно із таким його прочитанням, «неправильно» розумів джерела і сенс філософії: вона насправді «проростає» знизу, із буденності людського життя, а не «сходить» зверху як приклад іншого, небуденного способу екзистенції. Якщо враховувати, що більшість античних філософів сповідувала небуденність філософського життя, то Гайдегерова критика Аристотеля поширюється і на них.

Можна шукати різні визначення Гайдегерового способу інтерпретації. Наприклад, Герман Філіпс каже про «мета-Аристотелеву тематику» (meta-Aristotelian theme) у філософії Гайдегера, про те, що німецький філософ, насправді, завжди виходить за рамки Стагіритової думки (Heidegger uses, or seems to use, Aristotle with the objective of going beyond Aristotle) [Philipse, 1998: p. 77]. «Гайдегер інтерпретує Аристотелеве поняття філософії з перспективи власного розуміння цього поняття, що походить від Лютера, К’єркегора і Дильтая» [Philipse, 1998: p. 81]. У такому разі важливо усвідомлювати, що Гайдегерове звернення до Аристотеля, на відміну від звернення до апостола Павла, відкриває нам не первинний автентичний досвід, а досвід, який за допомогою деструкиії ще треба звільнити від спотвореного тлумачення.

Зрозуміло, що з позиції Гайдегера автентична інтерпретація як така зовсім не заперечується, але отримує новий сенс. Автентично тлумачити текст означає не 
спробу реконструювати внутрішню логіку тексту, не намагання проникнути у намір автора, а передусім - спробу усвідомити ситуацію, в якій перебуває сам інтерпретатор. Йдеться про те, аби прояснити власну «герменевтичну ситуацію». Якщо ж брати до уваги ту «герменевтичну ситуацію», в якій локалізує себе Гайдегер (включаючи обрані ним засоби екзегези), то ми мусимо взагалі залишити осторонь такі поняття, як «адекватна інтерпретація» у звичному і поширеному сенсі. Нас має цікавити зовсім інше. Саме зустріч із думкою Аристотеля (так зване «повторне звернення» до Стагірита після схоластичного прочитання) відкрило для Гайдегера нові можливості мислення. I нам важливо упрозорити ці можливості, випробувати їх практичну «придатність» (як сказав би Платон). В рамках Аристотелевої екзегези були зроблені не тільки перші кроки назустріч головним ідеям «Буття й часу», але й була вироблена властива Гайдегерові методологія (герменевтична феноменологія, герменевтична онтологія, метод герменевтичної деструкції).

Саме до аналізу Гайдегерової методології (викладеній у другій частині «Експозиції герменевтичної ситуації») ми зараз і звернемося. Гайдегер тематизує різні модуси «як» рухливості життя, описує тенденції життя до падіння у світ і тенденції, що можуть протидіяти падінню і розпаду фактичного життя. Філософія називається однією 3 життєвих тенденцій, вона є своєрідним експліцитним виповненням тенденції тлумачити дані глибинні рухи життя. Філософія має намір привести фактичне життя у його вирішальній буттєвій можливості до очевидності й схоплення [див. Хайдеггер, 2012: c. 81]. Висловлюючись коротше: філософія уможливлює екзистенцію.

Тут ми знаходимо твердження, що дозволяє зрозуміти перехід Гайдегера від апостола Павла до Аристотеля як рух у бік іншого первинного досвіду, ніж досвід християнської фактичності. Філософія наважується вивести фактичне життя зі стану самовідчуження, але вона буде спроможна це зробити тільки як атеїстична філософiя. Йдеться не про безбожність філософії (наприклад, - не про свідоме заперечення існування Бога), а про її онтологічне місце й роль. У примітці Гайдегер пояснює, що «атеїстичність» позначає свідоме рішення «триматися подалі від спокусливої, лише провокуючої релігійної стурбованості» [див. Хайдеггер, 2012: с. 82]. Чи можна ці слова тлумачити так, що релігійний досвід не $є$ шуканим первинним досвідом, а, навпаки, може постати виразником тенденції до падіння у світ? Тут виникає дуже цікава проблема. Практична філософія Аристотеля подається Гайдегером як взірцевий приклад походження розуміння з самого життя. У понятті phronêsis життя, практичні учинки і розуміння представлені у нерозривній єдності. Концептуальна система настільки ще занурена у праксис, що видається невід'ємною його частиною і його специфічним виявом. Так, для Аристотеля «теорія» є чимось божественним. Але у нього ідея божественного не походить із якогось особливого релігійного досвіду. Божественне є виразом для найвищого буттєвого характеру [див. Хайдеггер, 2012: с. 146]. Отже, теологія має виразні онтологічні конотації.

Як я вже зазначав, Гайдегер виходить із припущення, що в текстах Аристотеля описується не сам первинний досвід й автентична його інтерпретація (як це було в апостольських посланнях), а досвід, вже перетлумачений через традицію. Саме тому мислити разом з Аристотелем означає для Гайдегера піддати філософію Аристотеля деструкції, здійснити критичний перегляд іiі головних засад. Здається, що цей нюанс не помітив Андрій Богачов. Принаймні непросто зрозуміти таку його фразу: «Гайдегер стверджував щодо Аристотеля, що той, не будучи обтяжений змістом понять попередників (!!! - А.Б.), виражав у поняттях “структуру життя”» [Богачов 2011: 
c. 234]. Тобто Аристотель вперие здійснює концептуалізацію фактичного досвіду (життя). Проте, як ми це бачили, філософія Стагірита, за Гайдегером, «виражає» цей досвід таким чином, що сама потребує деструкції. Адже автентична інтерпретація досвіду подається у Аристотеля у перспективі хибно витлумаченої першої філософії. «Справжнє» у Стагіритовому розумінні варто вивільнити 3-під влади «несправжнього». Сама по собі філософія Аристотеля ще не є прикладом автентичного концептуального витлумачення життя. Ії необхідно «перезавантажити» і тільки тоді вона відкриє нам доступ до первинного досвіду.

Проте й первинний християнський досвід, як би ми його не тлумачили, все ж не може розумітися як іманентно-життєвий досвід якоїсь громади або спільноти. Так або інакше «християнська фактичність» має трансцендентне походження. Християнське життя, пояснюване в термінах іманентності, буде залишатися до певної міри незрозумілим або хибно витлумачуваним. Так само і в Аристотелевій теорії чеснот (i зокрема - в теорії phronêsis) не йдеться про щось іманентне. Але, знову ж таки, я тут виходжу з презумпції слушності Гайдегерової інтерпретації.

Нам відкриваються підходи до по-новому інтерпретованої онтології. Головне питання філософії стосується «буття фактичного життя». У такому аспекті філософія постає як «принципова онтологія», як «онтологія фактичності», з якої походять окремі світові регіональні онтології [див. Хайдеггер, 2012: с. 84]. Якщо приймати цю тезу, то як розуміти первинний досвід, зображуваний у «Феноменології релігії», той досвід, що зображується в інтерпретації Аристотеля? Чи можна уважати ці два образи фактичного життя за різні вияви єдиного первинного досвіду (з урахуванням наших вищенаведених зауважень), чи слід уважати їх радше за приклади різних регіональних онтологій? Навряд чи. Йдеться, на мою думку, про те, аби «категоріально упрозорити» конкретні тлумачення фактичного життя. I це можливо зробити тільки в рамках феноменологічної герменевтики фактичності [див. Хайдеггер, 2012: c. 85]. Герменевтика $є$ феноменологічною тому, що фактичне життя у своїх онтологічних модусах убачається як феномен. Феноменологія ж є герменевтичною тому, що фактичне життя як феномен спочатку не дається у своїй справжній фактичнос$m i$, у власній фактичності. Через свою схильність до падіння фактичне життя проживає переважно у модусі невласного, тобто в модусі успадкованого, в тому, що їй подане, що вона собі привласнює у певний посередній спосіб [див. Хайдеггер, 2012: c. 89]. У цей процес засвоєння «невласного» залучена і філософія, позаяк вона $є$ лише експліцитним тлумаченням фактичного життя. Саме тому феноменологічна герменевтика бере свій початок завжди у певній фактичній ситуації, у передданій витлумаченості фактичного життя [див. Хайдеггер, 2012: с. 90]. Отже, у конкретній фактичній ситуації (у герменевтичній ситуаціі) певне самотлумачення фактичного життя завжди і кожний раз уже «захоплене», утримуване «не-автентичністю», невласним проживанням, невласною фактичністю. Іншими словами, феномен життя показує себе не так, як він власне $\epsilon$, не так, як він має «власним чином» перебувати. Показування і приховування утворюють парадоксальну єдність. Сама ця прихованість пов'язана 3 внутрішньою тенденцією життя до падіння і розпаду. В «Бутті й часі» Гайдегер буде репрезентувати таку позицію як творчий розвиток феноменології. Але мені здається, що це шлях до ії скасування...

Гайдегер не каже, чому відбувається процес падіння у невласне, а прагне показати як $i$ в яких формах це падіння відбувається. Християнська фактичність падає в той момент, коли концептуальні схеми апостола Павла, які походять із первинного досвіду 
життя раннього християнства, перетлумачуються у термінах ранньої патристики, а потім - у Августина. Тим самими ми втрачаємо первинний досвід: власна фактичність упадає у «посередню витлумаченість» патристичної традиції. У свою чергу, концептуальна схема несправжнього тлумачення спирається на концептуальний фундамент грецької філософії. Тут ми можемо виявити внутрішню мотивацію звернення до Аристотеля. Філософія нинішньої ситуації переважно обертається в межах грецької концептуальності (Begrifflichkeit), що сама проходить крізь цілу низку різноманітних інтерпретацій. Основні поняття втратили свої первинні функції вираження [див. Хайдеггер, 2012: с. 93]. 3 іншого боку, ці концептуальні схеми зберігають певний характер власного походження, містять певну частину автентичної традищії свого вихідного сенсу. Сучасна філософія обертається у побічних відгалуженнях від «основного досвіду», що був виявлений у грецькій етиці і, передусім, у християнській ідеї людини і людського буття (Dasein) [див. Хайдеггер, 2012: с. 93]. Тут Гайдегер ніби перекидає місточок від Аристотеля до Павла і від Павла до Аристотеля. Основний досвід і автентична традиція (1) виявили себе в конкретній ситуації, (2) були витлумачені у певних концептуальних схемах і (3) підпали під несправжнє тлумачення у традиції. Та оскільки (4) навіть концептуальні схеми несправжнього тлумачення зберігають зв'язок із автентичною традицією і основним (первинним) досвідом, завжди відкрита можливість (5) повернутися до первинного досвіду і автентичної традиції.

Феномен власної фактичності прихований у феномені невласної фактичності. Неавтентична традиція імпліцитно містить у собі джерела автентичної традиції. Перехід же від одного феномену до іншого (виявлення прихованого) здійснюється в рамках і засобами тлумачення текстів і концептуальних систем. Феномен (фактичне життя) витлумачується у системі понять, що онтологічно (життєво) пов'язані із цим феноменом. Система понять існує в традиції і текстах (в мові, в різноманітних ситуаціях ужитку мови). Виходячи із ситуації «тут і тепер» ми можемо здійснити зворотній рух: піддати критиці несправжню концептуальність аби відкрити собі доступ до автентичної традиції і первинного досвіду.

У такому зворотному рухові (виявлення прихованого, віднайдення первинного, розкриття власного й автентичного) полягає застосовуваний Гайдегером метод деструкціï. Феноменологічна герменевтика фактичності вбачає своє покликання в тому, щоб послабити успадковану і пануючу витлумаченість в аспекті їі прихованих мотивів, неексплікованих тенденцій і способів тлумачення, і просунутися вперед на шляху деструктивного повернення (im abbauenden Rückgang) до мотиваційних першоджерел експлікації [див. Хайдеггер, 2012: с. 94]. Йдеться про радикальну можливість «освоєння традиції». Герменевтика здійснює своє завдання тільки на шляху деструкuзї [див. там само]. На такому шляху деструкції «теперішнє» зустрічається зі самим собою «у своїх власних глибинних рухах», відкриваючись назустріч можливостям основного досвіду і його тлумачень [див. Хайдеггер, 2012: с. 95]. У відмові від первинного тлумачення, фактичне життя відмовляється від можливості бути у власний спосіб. Але можливість повернення до автентичного завжди відкрита й імпліцитно міститься у кожному «ході» тлумачення і в кожному моменті фактичного життя.

\section{2. Апорії феноменологічної (фундаментальної) онтології}

Важливо зафіксувати цей момент: Гайдегерова концепція власного, справжнього буття (фактичного життя) спирається на імпліцитні нормативістичні припущення. Так само й розуміння традиції і тлумачення описується з позицій прихованого норма- 
тивізму. Думка Гайдегера рухається в межах таких опозицій: (1) власне - невласне, справжнє - несправжнє буття (фактичне життя), (2) автентична - неавтентична традиція, справжня - несправжня інтерпретація (тлумачення) тощо. Однак чому первинному досвіду приписується властивість бути справжнім і автентичним? Чому справжність і автентичність постають у модусі часового передування? I що ми маємо розуміти під «автентичною традицією»? Адже складається враження, що сама традиція тлумачиться Гайдегером як історія падіння (відпадіння). Наталя Артеменко пропонує розуміти амбівалентність Гайдегерового поняття «традиція» так: «Деструктивна настанова має бути спрямована не проти традиції, а проти того неусвідомленого і несправжнього способу, у який ми в ній поводимося» [Артеменко, 2012: с. 48]. Але це ще не скасовує запитання про критерій нормативності.

Зрозуміло, що повернення до автентичного життя становить частину тієї ж таки традиції. Принаймні з того способу, яким описується у «раннього» Гайдегера історія інтелектуальної традиції, можна зробити висновок, що «відпадіння» від первинного досвіду життя і від його справжнього тлумачення має постійну тенденцію до поглиблення. 3 одного боку, нечисленні спроби «повернути» традицію у напрямі автентичності слід уважати за невдалі [див. Хайдеггер, 2012: С. 96-97]. 3 іншого ж, досі ще не була здійснена «автентична інтерпретація» історії впливів й інтелектуальної тяглості [див. Хайдеггер, 2012: с. 98]. Позаяк ця «автентична інтерпретація» пов’язується тут із проблематикою фактичності, стає зрозумілим, що Гайдегер розуміє власний досвід мислення як одне із вирішальних буттєвих звершень в історії традиції й історії буття.

Нарешті, сам термін «фактичне життя» в світлі проведеного аналізу Гайдегерових міркувань породжує більше запитань, ніж дає відповідей. Поступово «життя» вбирає в себе стільки значень, що нам уже важко їх поєднати між собою.

Гайдегер орієнтується на грецький термін $d z \hat{\theta} \hat{e}$, який позначає і життя, і образ життя, і власність (життєві засоби). Термін $d z \hat{e} e$ позначає основний феномен, в якому центрується грецька, старозавітна, християнська новозавітна і греко-християнська інтерпретації людського буття [див. Хайдеггер, 2012: с. 56]. I якщо спочатку Гайдегер свідомо обирає багатозначність терміна $d z \hat{e} e$ орієнтиром власних пошуків, то поступово ця багатозначність починає все більше виявляти свій не-онтологічний потенціал. Справа також у тому, що тільки грецька мова тримає у єдності багатозначність $d z \hat{e} \hat{e} . \mathrm{У}$ процесі перекладу цього терміна на латину, а тим більше на європейські національні мови, термін втрачає свої онтологічні значення і зусилля по його філософський реабілітації не досягають успіху. Не випадково Гайдегер пізніше відмовляється від поняття «фактичне життя» на користь Dasein. Ми бачили, що «тут-буття» вводиться Гайдегером поступово й у лекціях з Аристотеля вживається як синонім «фактичного життя», хоч і в значно меншій кількості випадків.

За термінологічною невизначеністю стоїть і концептуальна непрозорість «фактичного життя». 3 одного боку, Гайдегер каже про конкретне людське життя, про «завжди моє власне» життя. 3 іншого ж, якщо б ми розуміли це життя як життя Петра або Марії (як життя конкретної особи), то таке розуміння не відповідало би Гайдегеровим інтенціям. Адже він намагається здійснити категоріальну експлікацію життя, каже про фундаментальні властивості, схильності і тенденції фактичного життя. Це щось до-персональне, або таке, що лежить в основі особового буття. Іноді навіть виникає підозра у гіпостазуванні поняття das faktische Leben. Наприклад, в одному місці стверджується, що Аристотель іде разом із фактичним життям у його (тобто, життя) власній спрямованості тлумачення (Aristoteles geht mit dem faktischen 
Leben in dessen eigener Auslegungsrichtung mit), він знову бере із самого життя способи «прийняття за [щось]» (er nimmt wiederum aus ihm selbst die Dafürnahmen auf), в яких певна людина описується як «мудра», тобто така, що властивим чином розуміє (als eigentlich Verstehenden) [див. Хайдеггер, 2012: с. 144]. Ми можемо часто зустріти такі звороти, як «життя тлумачить себе», «життя має схильність», «життя має тенденцію». Життя розуміє, тлумачить, турбується, прагне, потребує, спокушається, заспокоюється, відчужується від себе, падає, розкладається, повертається до себе тощо. Здається, що Гайдегер створює онтологію як біографію, як життєпис певної істоти, що втілюється у різноманітних персонажах (носіях життя, репрезентантах життя) і переживає різноманітні стадії розвитку. Припускається, що фактичне життя діє в кожному з нас, направляє нас і керує нами. Не ми проживаємо життя, а життя живе в кожному з нас у своїх типових модусах і тенденціях.

Мало того, що фактичне життя описується у квазі-персоналістичних термінах. Гайдегер до того ж будує онтологічну біографію на прихованих нормативних заснов$\kappa a x$, які жодним чином не пояснюються і не витлумачуються в рамках запропонованого нам наративу. Поняття первинності, автентичності, справжності, власності аж ніяк не випливають з проекту феноменологічної онтології. 3 контексту можна зрозуміти, що критерії первинності/автентичності/справжності/власності містяться у самому фактичному житті. Чим ближче концептуальні системи й інтерпретації до фактичного життя, тим вони автентичніші й справжніші. Але якщо саме фактичне життя $\epsilon$ носієм і фундаментом нормативності, то зовсім незрозуміло, 3 яких підстав один досвід позначається як первинний, а інший описується як вторинний і спотворений. На мій погляд, можливі два варіанта відповіді (не враховуючи релігійної і міфологічної відповідей про рай або золотий вік). (1) Досвід є первинним, бо він $є$ історично (життєво) першою подією у часі. Це темпоральне й історичне розуміння первинності. Наприклад, Марія стала першою людиною, яка скуштувала нову марку шоколадних цукерок (перша в історії і перша за часом). А Петро пережив перше у своєму житті кохання (тобто, отримав перший досвід). Ці приклади $\epsilon$ нейтральними щодо автентичності/не-автентичності або справжності/не-справжності. Лише повторення згаданих досвідів можуть ввести у гру згадані опозиції. Наприклад, скуштувавши багато шоколадних цукерок, Марія може сказати, що ті перші цукерки не смакували як справжній шоколад. А Петро пізніше зрозумів, що то була не справжня любов а скороминуща закоханість. Висновок простий: те, що є першим у часі, не $є$ первинним у значенні автентичності й справжності. Друга відповідь: досвід $є$ первинним не за часом, а в аспекті значущості. Це онтологічне $i$ нормативне розуміння первинності. Аристотель розрізняв первинне за часом (tô de chronô proteron, tempore prius) і первинне згідно із сенсом (kata ton logon, secundum rationem). Іноді він каже про первинне «саме по собі», «як таке». Наприклад, акт первинний стосовно потенції, а вічність стосовно часу. У пізній схоластиці почали розрізняти a posteriori й a priori. Кант i Гусерль кажуть про самосвідомість як першоджерело досвіду (про апріорне першоджерело), а сучасна філософія розрізняє рівень значущості (нормативність) й рівень походження (генетичний рівень).

Коли ж Гайдегер критикує такий апріоризм і намагається віднайти першоджерела досвіду не в самосвідомості, а в первинному досвіді фактичного життя (позначеному історичністю й часовістю), то він зобов'язаний або надати контр-пояснення нормативності такого первинного досвіду, або взагалі відмовитися від квазі-нормативістичної мови. Фундаментальна онтологія якраз і задумується як контр-проект, 
контр-пояснення основних буттєвих структур фактичного життя (пізніше - фундаментальних структур Dasein). Але як у лекціях 20-х років, так і в «Бутті й часі», онтологічне i нормативне розуміння первинного досвіду Гайдегер намагається витлумачити у перспективі його темпорального й історичного розуміння. Онтологія занурюється в стихію історичності. Тим самим поняття первинного досвіду і фактичного життя наражаються на нерозв'язувані суперечності.

Наприклад, зовсім незрозуміло як у самому фактичному житті виникають ціннісні розрізнення. Бо, наприклад, тенденція до падіння називається позитивною і тлумачиться по-суті як шлях до екзистенції. Тобто, немає сенсу взагалі казати про справжнє/несправжнє. Йдеться про різні маніфестації того самого фактичного життя, в рамках якого виправдані й необхідні всі його «нахили» і «тенденції». Будьяка, навіть найабсурдніша інтерпретація, може бути проголошена доленосною і «спасенною».

\section{Висновки}

Звідки походять ці апорії Гайдегерового проекту феноменологічної онтології? I до чого вони, врешті-решт, приводять його думку? Попередня відповідь може бути такою.

1. Гайдегер підходить до феноменів життя, описаних у Аристотеля, спираючись на засновки $i$ передумови, які перебувають у жорсткій опозииії до засновків $i$ передумов згаданих авторів. Інтерпретації Гайдегера є насильницькими не тому, що вони абсолютно хибні (ми домовилися не вживати до його інтерпретацій таких оціночних суджень). Вони є насильницькими тому, що Гайдегер змушує Аристотеля невластивою для останнього мовою проголошувати чужі ідеї. Він свавільно руйнує його концептуальні системи і не бере до уваги дійсні мотиви його мислення (хоча i стверджує, що його мета полягає саме у віднайдені первинного досвіду життя). Сказане не означає, що Гайдегеровим інтерпретаціям слід відмовити у праві на існування, що їх треба оголосити нелегітимними. Навіть з огляду на самі лише імена його учнів і послідовників, на їхні філософські досягнення (в тому числі й у сфері досліджень 3 античної філософії) не можна говорити про якусь нелегітимність.

Йдеться про цілком різні речі. Одна справа казати про потужний герменевтичний ресурс і пояснювальний потенціал Гайдегерових інтерпретацій, що є безсумнівними. I зовсім інша - про приховані апорії і кінцеву невдачу Гайдегерових інтерпретацій. Адже невдачі або провали (а провалом, як я вже згадував, сам Гайдегер називав спочатку «Буття й час», а потім і всю філософську традицію Заходу) можуть також бути вельми продуктивними у справі мислення.

2. Нарешті можна стверджувати, і це є ще важливішим для нашого дослідження, що феноменологічна онтологія спирається на засновки $і$ передумови, які є прихованими $i$ непроясненими для самого Гайдетера. Тому я намагаюся застосувати Гайдегерів метод герменевтичної деструкції до його власного мислення. В лекційному курсі літнього семестру 1923 року «Онтологія (герменевтика фактичності)» Гайдегер поєднає обидві лінії інтерпретації (релігійного досвіду раннього християнства і філософії Аристотеля). Ідеї, викладені у цих лекціях, стануть першим начерком фундаментальної онтології як оригінального проекту Гайдегерової філософії. Але показана нами апоретичність і непроясненість базових передумов Гайдегерового мислення не тільки не отримає розв'язання, але стане ще глибшою. 


\section{СПИСОК ЛІТЕРАТУРИ}

Артеменко Н.А. Хайдеггеровская «потерянная рукопись» на пути к «Бытию и времени». СПб.: Гуманитарная Академия, 2012. - 128 с.

Богачов А. Досвід і сенс. - К.: Дух і літера, 2011. -336 с.

Гадамер Г.-Г. Пути Хайдеггера: исследования позднего творчества. - Минск: Пропилеи, 2007. $-239 \mathrm{c}$.

Хайдеггер М. Феноменологическая интерпретация Аристотеля (экспозиция герменевтической ситуации). - СПб.: Гуманитарная Академия, 2012. - 224 с.

Figal G. Heidegger zur Einführung. - Hamburg: Junius, 1992. - 193 S.

Heidegger M. Phänomenologie Interpretationen zu Aristoteles. Einführung in die phänomenologische Forschung / Hrsg. Walter Bröcker und Käte Bröcker-Oltmanns // Heidegger M. Gesamtausgabe: Bd. 61. - Frankfurt am Main: Vittorio Klostermann, 1994. - 203 S.

Kisiel T. The Genesis of Heidegger's Being and Time. - Berkeley and Los Angeles: University of California Press, 1993. -608 p.

Philipse H. Heidegger's Philosophy of Being. A critical interpretation. - Princeton: Princeton UP, 1998. $-555 \mathrm{p}$.

Стаття одержана редакцією 18.11.2012

\section{Andrii Baumeister \\ ON THE WAY TO THE AUTHENTIC BEING: PHENOMENOLOGICAL DESTRUCTION OF ARISTOTLE IN EARLY HEIDEGGER'S TEACHING}

The article investigates specific features of phenomenological destruction of Aristotle by early Heidegger. Interpretation of Aristotle's philosophy is considered in the light of his developing the project of fundamental ontology and first approaches to «Being and time». Heidegger's interpretation of Aristotle's thinking, on the one hand, has considerable hermeneutics potential, but, on the other hand, violently reinterprets the main motives and principles of Aristotle's philosophy. Heidegger in his interpretation of Aristotle's texts proceeds from not quite clarified presuppositions and implicitly uses in his exegesis quasi-normativistic and quasipersonalistics conceptual schemes.

Andrii Baumeister, PhD in philosophy, Associate professor of the Philosophy Department, Taras Shevchenko National University of Kyiv.

Андрій Баумейстер, кандидат філософських наук, докторант філософського факультету Київського національного університету імені Тараса Шевченка.

Андрей Баумейстер, кандидат философских наук, докторант философского факультета Киевского начионального университета имени Тараса Шевченко. 